\title{
Strategi Fundrasing Wakaf Di Badan Wakaf Pondok Pesantren Mawaridussalam
}

\author{
M Guffar Harahap \\ Universitas Islam Negeri Sumatera Utara \\ medanguffar@gmail.com
}

\begin{abstract}
Waqf is one of the teachings that is very noticed in Islam and has socioeconomic value for the welfare of society. The principle of property ownership in Islam states that property is not justified by a group of people. Along with the development of the waqf era it is now in the form of productive money and endowments. With this development the government also expanded the waqf property, one of which was money waqf as stated in Government Regulation No.42 of 2006. However, among the reality of the understanding of the development of waqf this was not widely known by the public. In general, people understand waqf more traditionally both from harmony, the terms and purpose of holding waqf itself. Like the distribution of waqf for the sake of worship. In addition, the level of expertise and knowledge of waqf nadzir as the main actors in waqf fundraising to the community has not been maximally developed for waqf fundraising strategies to attract the waqf, among others, just waiting for the waqif candidates to endow their assets. If this condition is not addressed, it can result in waqf not being optimal and developing. Based on this, it does not cover the possibility of waqf boarding schools to anticipate this. This study aims to find out about waqf fundraising strategies in mawaridussalam Islamic boarding schools and their impact. The research methods used were observation, interviews, SWOT analysis with a qualitative approach. The results of the study showed that fundraising strategies were used by waqf institutions of mawaridussalam islamic boarding school, namely annual events (building community trust), socialization of santri to their families, stocking up, endowments and waqf coaching.
\end{abstract}

Keywords: Strategy, Fundraising, Waqf

Abstrak

Wakaf merupakan salah satu ajaran yang sangat di perhatikan dalam Islam dan memiliki nilai sosial ekonomi untuk kesejahteraan masyarakat.Prinsip kepemilikan harta dalam Islam menyatakan bahwa harta tidak dibenarkan dikuasai oleh sekelompok orang. Seiring dengan perkembangan jaman wakaf kini sudah berupa uang dan wakaf produktif. Dengan perkembangan ini pemerintah juga memperluas harta wakaf salah satunya wakaf uang seperti yang tercantum di dalam Peraturan Pemerintah No.42 Tahun 2006. Namun diantara realitanya pemahaman tentang perkembangan wakaf ini tidak banyak diketahui oleh masyarakat. Pada umumnya masyarakat memahami wakaf lebih bersifat tradisional baik dari rukun, syarat dan maksud diadakannya wakaf itu sendiri. Seperti penyaluran wakaf untuk kepentingan ibadah. Di samping itu tingkat keahlian dan pengatahuan nadzir wakaf sebagai pelaku utama dalam fundraising wakaf kepada masyarakat belum maksimal mengembangkan strategi fundraising wakaf untuk menarik pewakaf, diantaranya hanya menunggu calon wakif untuk 
mewakafkan hartanya. Jika kondisi ini tidak ditangani dapat mengakibat wakaf tidak optimal dan berkembang. Berdasarkan hal tersebut, tidak menutupi kemungkinan badan wakaf pondok pesantren untuk mengantisipasi hal demikian. Penelitian ini bertujuan untuk mengetahui tentang strategi fundraising wakaf di pondok pesantren mawaridussalam dan dampaknya. Metode penelitian yang digunakan adalah observasi, wawancara, analisis SWOT dengan pendekatan kualitatif. Hasil penelitian menunjukkan strategi fundraising yang digunakan badan wakaf pondok pesantren mawaridussalam yakni acara tahunan (memabangun kepercayaan masyarakat), sosialisasi santri kepada keluarganya, stokeholder, jemput wakaf dan pembinaan wakif.

Kata Kunci: Strategi, Fundraising, Wakaf

\section{Pendahuluan}

Wakaf adalah salah satu ajaran yang sangat diperhatikan dalam Islam dan memiliki nilai sosial ekonomi untuk kesejahteraan masyarakat. Menurut pandangan Islam pemilik mutlak seluruh harta benda ialah Allah SWT. Manusia ditunjuk oleh Allah sebagai penguasa terhadap benda itu yang harus mengelolanya sesuai dengan petunjuk-NYA. Yaitu digunakan untuk keperluan dirinya dan manfaat bagi kesejahteraan dan kemaslahatan umat manusia pada umumnya. ${ }^{1}$

Prinsip kepemilikan harta dalam Islam menyatakan bahwa harta tidak dibenarkan dikuasai oleh sekelompok orang. Karena akan melahirkan eksploitasi kelompok minoritas (si kaya) terhadap kelompok mayoritas (si miskin) yang akan menimbulkan kecemburuan sosial dan menjadi penyakit masyarakat yang mempunyai akibat-akibat negatif yang beraneka ragam. Karena pada hakikatnya harta merupakan sebuah titipan, maka tidak dapat memilikinya secara mutlak sehingga dalam pandangan tentang harta terdapat hak-hak orang lain seperti zakat, sedekah, wakaf dan memanfaatkan harta dijalan Allah SWT. ${ }^{2}$

Wakaf bukan hanya shadaqah biasa, tetapi merupakan shadaqah yang memiliki nilai lebih dari pada shadaqah-shadaqah lain. Wakaf bisa menjadi jalan dan perantara untuk memajukan agama serta membangun masyarakat dalam berbagai bidang kehidupan, seperti Ibadah, pendidikan, dakwah, sosial, kesehatan dan lainnya. ${ }^{3}$

Wakaf merupakan satu dari banyak kegiatan bermuamalah dalam Islam. Dalam istilah syara secara umum, wakaf adalah sejenis pemberian yang 
pelaksanaannya dilakukan dengan jalan menahan (pemilik) asal, lalu menjadikan manfaatnya berlaku umum. ${ }^{4}$ Esensi menahan harta wakaf inilah yang kemudian menjadi sebuah potensi yang baik melalui wakaf dalam mengusahakan perkembangan kepentingan sarana dan prasarana sosial masyarakat.

Dr. Mustafa Edwin (Dosen PPS Universitas Indonesia), pernah menghitung potensi cash wakaf. Menurutnya jika potensi ini digali oleh lembaga professional, maka dalam satu tahun menurutnya bisa terkumpul dana sebesar Rp 3 Triliun. Perkiraan tersebut wajar saja, mengingat jumlah ummat Islam di Indonesia lebih 180 juta jiwa. Kalau 10 juta saja diantaranya yang berwakaf uang dengan nominal masing-masing Rp.100.000, maka dalam setahun terkumpul Rp. 1 triliun. $^{5}$

Seiring dengan perkembangan jaman, wakaf kini sudah berupa uang dan wakaf-wakaf produktif. Dengan perkembangan ini, pemerintah juga memperluas bentuk harta wakaf, salah satunya ialah wakaf uang, seperti yang tercantum dalam Peraturan Pemerintah No. 42 Tahun $2006 .{ }^{6}$ Namun pada realitanya, pemahaman tentang perkembangan wakaf ini tidak banyak diketahui oleh masyarakat Indonesia tentang arah, urgensi dan hukum wakaf itu sendiri. Pada umumnya, masyarakat memahami wakaf lebih bersifat tradisional, baik dari segi rukun, syarat, dan maksud diadakannya wakaf itu sendiri. Seperti memahami penyaluran wakaf hanya untuk kepentingan ibadah (Mesjid). Kurangnya pemahaman masyarakat mengenai esensi wakaf dan peranannya dalam pembangunan, menjadikan semangat berwakaf sangat rendah.

Problematika selanjutnya adalah strategi yang belum maksimal berdampak pada produktifitas dari harta wakaf itu sendiri, Problematika ini yang menjadikan sebuah dorongan bahwa sebuah lembaga wakaf, dibutuhkan sebuah strategi fundraising wakaf yang baik agar dana pengembangan maupun harta-harta wakaf dapat optimal.

Tidak berkembangnya strategi fundraising yang diterapkan dalam sebuah lembaga atau organisasi, baik dalam konteks awal perencanaan maupun pengawasan oleh pengelola lembaga dengan berbagai perspektif manajemen modern yang ada dapat mengakibatkan orientasi wakaf tidak berjalan dengan baik, 
beberapa rumpun manajemen yang perlu di eksploitasi untuk mengembangkan fundraising dalam sebuah lembaga, yaitu manajemen pemasaran (marketing management) dan manajemen produksi/operasi. Fungsi pemasaran berkenaan dengan sisi permintaan-relasi dengan para konsumen (demand side). Selanjutnya, fungsi produksi/operasi berurusan dengan penciptaan program-program fundraising yang menghasilkan (supply side).

Sebagai kerangka konsep tentang suatu kegiatan dalam rangka fundraising dana dari masyarakat yang akan digunakan untuk membiayai program dan kegiatan operasional lembaga sehingga mencapai tujuan. fundraising juga merupakan proses mempengaruhi masyarakat atau calon donatur agar mau melakukan amal kebajikan dalam bentuk penyerahan sebagian hartanya. Hal ini penting sebab sumber harta/dana berasal dari donasi masyarakat. Agar target bisa terpenuhi dan program bisa terwujud, diperlukan langkah-langkah strategis dalam menghimpun aset, yang selanjutnya akan dikelola dan dikembangkan.

Pondok Pesantren Mawaridussalam terdapat lembaga Wakaf yang sudah berdiri sebagai instrument ekonomi dalam manajemen pembiayaan pendidikannya. Setiap tahunnya dana wakaf terkumpul baik wakaf uang dan wakaf tidak bergerak. Dari penjelasan diatas dapat disimpulkan bahwa adanya suatu strategi yang diterapkan oleh pesantren sehingga mampu mengumpulkan harta wakaf. Namun belum memenuhi skala prioritas jika ditelaah kembali urgensi dari wakaf. Diantaranya kurangnya minat wakif untuk berwakaf sehingga tingkat partisipasi terlalu kecil dalam berwakaf.

\section{Strategi Fundraising}

Kata strategi berasal dari bahasa Yunani yaitu "strategas" (status: Militer dan Ag: memimpin) yang berarti “Generalship" atau sesuatu yang dikerjakan oleh para jenderal perang dalam membuat rencana untuk memenangkan perang. Konsep ini relevan pada zaman dahulu yang sering di warnai perang dimana jendral dibutuhkan untuk memimipin sesuatu angkatan perang. ${ }^{7}$ Strategi adalah ilmu dan seni menggunakan semua sumber daya bangsa-bangsa untuk melaksanakan kebijakan tertentu di dalam perang dan damai, atau rencana yang 
cermat mengenai kegiatan untuk mencapai sasaran khusus. ${ }^{8}$ Juga disebutkan bahwa strategi berarti rencana yang cermat mengenai kegiatan untuk mencapai sasaran khusus.

Manajemen strategi dapat didefinisikan sebagai seni dan ilmu untuk memformulasi, mengimplementasi dan mengevaluasi keputusan tingkat fungsi yang memungkinkan organisasi dapat mencapai tujuan. Manajemen strategi adalah perencanaan berskala besar (perencanaan strategis) yang berorientasi pada jangkauan masa depan yang jauh (visi), yang ditetapkan sebagai keputusan manajemen puncak atau keputusan yang bersifat standar dan prinsipil agar memungkinkan organisasi berinteraksi secara efektif (misi). ${ }^{9}$ Dalam usaha menghasilkan sesuatu perencanaan operasional untuk menghasilkan barang dan jasa serta pelayanan yang berkualitas, dengan di arahkan pada optimalisasi pencapaian tujuan strategi dan berbagai saran (tujuan operasional organisasi). ${ }^{10}$

\section{Proses Tahapan Strategi}

Strategi juga melalui berbagai tahap dalam prosesnya, secara garis besar strategi melalui tiga tahapan, yaitu $:^{11}$

a. Perumusan Strategi

Langkah pertama yang perlu dilakukan adalah merumuskan strategi yang akan di lakukan. Sudah termasuk di dalamnya adalah pengembangan tujuan, mengenai peluang dan ancaman eksternal, menetapkan kekuatan kelemahan secara internal, menetapkan suatu objektifitas, menghasilkan strategi alternatif, dan memilih strategi untuk dilaksanakan. Dalam perumusan strategi juga di tentukan suatu sikap untuk memutuskan, memperluas, menghindari atau melakukan suatu keputusan dalam proses kegiatan.

b. Implementasi Strategi

Setelah kita merumuskan dan memilih strategi yang telah di tetapkan, maka langkah berikutnya adalah melaksanakan strategi yang telah di tetapkan tersebut. Dalam tahap pelaksanaan strategi yang telah dipilih 
sangat membutuhkan komitmen dan kerjasama dari seluruh unit, tingkat dan anggota organisasi.

c. Evaluasi Strategi

Tahap akhir dari strategi ini adalah evaluasi. Strategi ini di perlukan karena keberhasilan yang telah dicapai dapat diukur kembali untuk menetapkan tujuan berikutnya. Evaluasi menjadi tolak ukur untuk strategi yang akan dilaksanakan kembali oleh suatu organisasi dan evaluasi sangat diperlukan untuk memastikan sasaran yang dinyatakan telah dicapai. Ada tiga macam kegiatan mendasar untuk mengevaluasi strategi, yakni :

Meninjau faktor-faktor eksternal dan internal yang menjadi dasar strategi. Adanya perubahan yang akan menjadi suatu hambatan dalam pencapaian tujuan, begitu pula dengan faktor internal yang diantaranya strategi tidak efektif atau hasil implementasi yang buruk dapat berakibat buruk pula bagi hasil yang akan dicapai.

Mengukur prestasi (membandingkan hasil yang diharapkan dengan kenyataan). Prosesnya dapat dilakukan dengan menyelidiki penyimpangan dari rencana, mengevalusasi prestasi individu dan menyimak kemajuan yang dibuat ke arah pencapai sasaran yang dinyatakan. Kriteria untuk mengevaluasi strategi harus dapat diukur dan mudah dibuktikan. Kriteria untuk meramalkan hasil lebih penting dari pada kriteria yang mengungkapkan apa yang terjadi.

Mengambil tindakan korektif untuk memastikan bahwa prestasi sesuai dengan rencana. Dalam hal ini tidak harus berarti bahwa strategi yang ada ditinggalkan atau harus merumuskan strategi yang baru. Tindakan korektif di perlukan bila tindakan atau hasil tidak sesuai yang dibayangkan semula atau pencapaian yang diharapkan.

Dari tahapan strategi di atas bahwa merumuskan, mengimplementasi dan mengevaluasi suatu strategi itu harus dilakukan untuk kelancaran sebuah kegiatan ataupun program. Karena fungsi merumuskan, mengimplementasi dan mengevaluasi dari sebuah strategi itu dapat mengembangkan sebuah tujuan yang akan dicapai. Dalam hal ini, suatu perusahaan atau lembaga akan dapat mengukur sejauh mana kegiatan atau program yang sudah di laksanakan dengan baik. 


\section{Konsep Fundraising}

Menurut bahasa fundraising berarti penghimpunan dana atau penggalanagan dana, sedengkan menurut istilah fundraising merupakan suatu upaya atau proses kegiatan dalam rangka menghimpun dana zakat, infak, dan sedekah, wakaf, serta sumber dana lainnya dari masyarakat baik individu, kelompok, organisasi dan perusahaan yang akan disalurkan dan didayagunakan untuk musthaik. ${ }^{12}$ Dari penjelasan diatas penulis menyimpulkan bahwa fundraising adalah sebuah cara untuk mempengaruhi masyarakat agar mau mengeluarkan sedikit penghasilannya untuk melakukan amal kebajikan dalam bentuk pemberian dana atau sumber daya lainnya yang bernilai, untuk diberikan kepada masyarakat yang berhak menerimanya seperti, kaum fakir, miskin dll.

Fundraising juga dapat diartikan proses mempengaruhi masyarakat baik perseorangan sebagai individu atau perwakilan masyarakat maupun lembaga agar menyalurkan dananya kepada sebuah organisasi. ${ }^{13}$ Kata mempengaruhi masyarakat mengandung banyak makna: Pertama, dalam kalimat diatas mempengaruhi bisa diartikan memberitahukan kepada masyarakat tentang seluk beluk keberadaan Lembaga Zakat atau Wakaf

Kedua, mempengaruhi dapat juga bermakna mengingatkan dan menyadarkan. Artinya mengingatkan kepada donator untuk sadar bahwa dalam harta yang dimilikinya bukan seluruhnya oleh dari usahanya secara mandiri. Karena manusia bukanlah lahir sebagai mahluk individu saja, tetapi juga memfungsikan dirinya sebagai mahluk sosial. Kesadaran yang seperti inilah yang diharapkan oleh lembaga perwakafan dalam mengingatkan para donator. Sehingga penyadaran dengan mengingatkan secara terus menerus menajdikan individu dan masyarakat terpengaruh dengan program dan kegiatan pemberdayaan masyarakat yang dilakukannya.

Ketiga, mempengaruhi dalam arti mendorong masyarakat, lembaga dan individu untuk menyerahkan sumbangan dana baik berupa zakat, infaq, sedekah, wakaf dan lain-lain kepada lembaga zakat dan wakaf dalam melakukan fundraising juga mendorong kepedulian sosial dengan memperhatikan prestasi kerja annual report kepada calon donator. Sehingga ada kepercayaan dari para calon donator setelah mempertimbangkan segala sesuatunya. 
Keempat, mempengaruhi untuk membujuk para donator untuk berinteraksi. Pada dasarnya keberhasilan suatu fundraising adalah keberhasilan dalam membujuk para donator untuk memberikan sumbangan dananya kepada organisasi pengelola zakat dan lembaga perwakafan. Maka tidak ada artinya suatu fundraising tanpa adanya interaksi.

Kelima, dalam mengartikan fundraising sebagai proses mempengaruhi masyarakat, mempengaruhi juga dapat diterjemahkan memberikan gambaran tentang bagaimana proses kerja, program dan kegiatan sehingga menyentuh dasardasar nurani seseorang. Gambaran-gambaran yang diberikan inilah yang diharapkan bisa mempengaruhi masyarakat sehingga mereka bersedia memberikan sebagian dana yang dimiliknya sebagai sumbangan dana zakat, infaq, shadaqah, dan wakaf kepada lembaga.

Keenam, mempengaruhi dalam pengertian fundraising dimaksudkan untuk memaksa jika diperkenankan. Bagi lembaga zakat dan wakaf, hal ini bukanlah suatu fitnah, atau kekhawatiran akan menimbulkan keburukan. Tentunya paksaan ini dilakukan dengan ahsan sebagai perintah Allah dalam Al-Qur'an yang berbunyi:

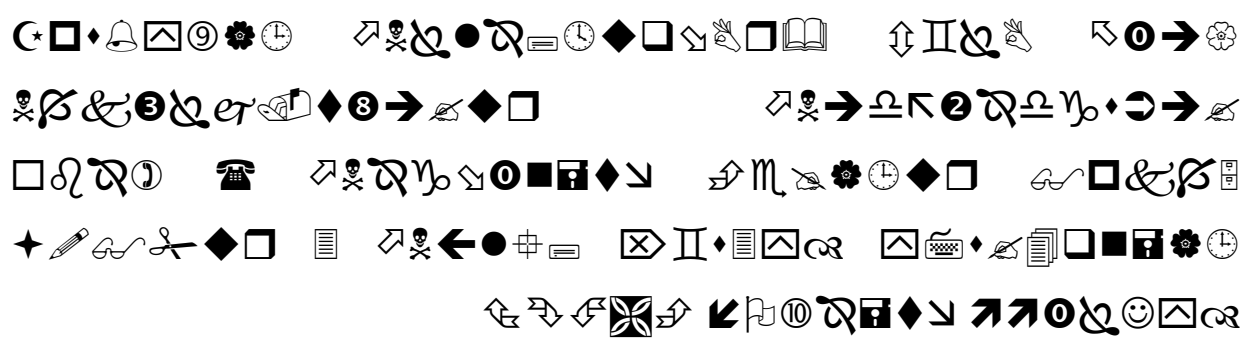

Artinya:“Ambillah shodaqah dari sebagian harta mereka, dengan zakat itu kamu membersihkan dan mensucikan mereka dan mendoalah untuk mereka.Sesungguhnya doa kamu itu (menjadi) ketenteraman jiwa bagi mereka. Dan Allah Maha Mendengar lagi Maha Mengetahui."

\section{Metode Fundraising Wakaf}

Dalam melaksanakan kegiatan fundraising, banyak metode dan teknik yang dapat dilakukan. Adapun yang dimaksud metode disini adalah suatu bentuk kegiatan yang khas yang dilakukan oleh sebuah organisasi dalam rangka menghimpun dana dari masyarakat. Metode ini pada dasarnya dapat dibagi 
kepada dua jenis, yaitu langsung (direct fundraising) dan tidak langsung (indirect). ${ }^{14}$

a. Metode fundraising langsung ( direct fundraising) yang dimaksud dengan metode ini adalah metode yang menggunakan teknik-teknik atau cara-cara yang melibatkan partisipasi wakif secara langsung, yaitu bentuk-bentuk fundraising dimana proses interaksi dan daya akomodasi terhadap respon wakif bisa seketika (langsung) dilakukan. Dengan metode ini apabila dalam diri wakif muncul keinginan untuk melakukan donasi setelah mendapatkan promosi dari fundraiser lembaga, maka segera dapat melakukan dengan mudah dan semua kelengkapan informasi yang diperlukan untuk melakukan donasi sudah tersedia. Sebagai contoh dari metode ini adalah: Direct Mail, Direct Advertising, Telefundraising dan presentasi langsung. ${ }^{15}$

b. Metode fundraising tidak langsung (indirect fundraising) metode ini adalah suatu metode yang menggunakan teknik-teknik atau caracara yang tidak melibatkan partisipasi wakif secara langsung, yaitu bentukbentuk fundraising dimana tidak dilakukan dengan memberikan daya akomodasi langsung terhadap respon wakif seketika. Metode ini misalnya dilakukan dengan metode promosi yang mengarah kepada pembentukan citra lembaga yang kuat, tanpa diarahkan untuk transaksi donasi pada saat itu. Sebagai contoh dari metode ini adalah: advertorial, image compaign dan penyelenggaraan event, melalui perantara, menjalin relasi, melalui referensi, dan mediasi para tokoh, dll

Pada umumnya sebuah lembaga melakukan kedua metode fundraising ini (langsung atau tidak langsung). Karena keduanya memiliki kelebihan dan tujuannya sendiri-sendiri. Metode fundraising langsung diperlukan karena tanpa metode langsung, wakif akan kesulitan untuk mendonasikan dananya. Sedangkan jika semua bentuk fundraising dilakukan secara langsung, maka tampak akan menjadi kaku, terbatas daya tembus lingkungan calon wakif dan berpotensi menciptakan kejenuhan. Kedua metode tersebut dapat digunakan secara fleksibel dan semua lembaga harus pandai mengkombinasikan kedua metode tersebut. 
310 AT-TAWASSUTH: Jurnal Ekonomi Islam, Volume IV No. 2 Juli Desember 2019: 301 - 322

Metode Penelitian

Penelitian ini menggunakan pendekatan penelitian kualitatif dengan beriorentasi pada kualitatif "Deskriptif" (Qualitative Descriptive Design). Pendekatan Kualitatif deskriptif pada umumnya merupakan penelitian non hiptesis sehingga dalam penelitian ini tidak diperlukan rumusan hipotesis. Penelitian kualitatif adalah sutau penelitian yang di tujukan untuk mendeskripsikan dan menganalisa fenomena, peristiwa, aktifitas sosial, sikap, kepercayaan, persepsi, pemikiran orang secara individu dan kelompok. Atas dasar itu, maka penelitian ini dilandasi dengan persepektif "fenmenologis" yang berusaha untuk memahami makna dari berbagai peristiwa dan interaksi manusiawi didalam situasinya yang khusus. ${ }^{16}$

Penelitian kualitatif adalah sebuah proses pemahaman yang dilakukan secara terus-menerus dengan mengamati suatu situasi tertentu atau fenomena sosial dan masalah manusia yang terjadi dalam kehidupan sehari-hari. Dengan kata lain, penelitian kualitatif mencoba memahami fenomena apa yang terjadi pada subjek penelitian baik sikap, perilaku, dan pandangan seseorang, dan di laporkan dengan cara deksripsi dalam bentuk kata-kata. Penelitian kualitatif adalah prosedur penelitian yang menghasilkan data deskriptif berupa kata-kata, tertulis atau lisan orang-orang, dan perilaku yang dapat di amati. ${ }^{17}$

Metode penelitian kualitatif adalah metode penelitian yang berlandaskan pada filsafat postpositivisme, digunakan untuk meneliti pada kondisi obyek yang alamiah, dimana peneliti adalah sebagai instrumen kunci, pengambilan sampel sumber data dilakukan secara purposive, Purposive berarti teknik pengambilan sampel secara sengaja. Maksudnya, peneliti menentukan sendiri sampel yang di ambil karena ada pertimbangan tertentu. Jadi sampel diambil tidak secara acak, tapi di tentukan sendiri oleh peneliti. teknik pengumpulan dengan trianggulasi (gabungan), analisis data bersifat induktif/kualitatif, dan hasil penelitian kualitatif lebih menekankan makna dari pada generalisasi. ${ }^{18}$

Penelitian kualitatif memiliki dua tujuan utama, yaitu menggambarkan dan mengunkapkan (to describe and explore) dan menggambarkan dan menjelaskan (to descibbe and explain), kualitatif yang digunakan bersifat eksploratidf yang 
bertujuan untuk menggambarkan keadaan atau fenomena tertentu. ${ }^{19}$ Dengan demikian penelitian ini sedemikan rupa berupaya member gambaran yang jelas serta terperinci, menjelaskan hubungan gejala-gejala pada strategi fundraising wakaf di badan wakaf pondok pesantren mawaridussalam.

Metode yang digunakan dalam penelitian kualitatif untuk pengumpulan data yaitu pengamatan (observasi), wawancara, dan dokumentasi. pertimbangan penggunaan metode pengamatan, wawancara, dan penelaah dokumen antara lain pertama, menyesuaikan metode kualitatif lebih mudah apabila berhadapan dengan kenyataan jamak. Kedua, metode ini menyajikan secara langsung hakikat hubungan antara peneliti dengan responden. Ketiga, metode ini lebih peka dan lebih dapat menyesuaikan diri dengan banyak penajaman pengaruh bersama terhadap pola-pola nilai yang dihadapi.

a. Observasi

Obeservasi diartikan sebagai pengamatan dan pencatatan secara sitematik terhadap gejala yang tampak pada objek penelitian baik pengamatan yang dilakukan secara langsung maupun tidak langsung. ${ }^{20}$

Observasi merupakan tahap pertama dan penting dalam sebuah penelitian, dimana observasi adalah kegiatan pengamatan yang dilakukan sebelum data yang lebih mendalam didapatkan. Dengan melakukan pengamatan diharapkan peneliti dapat melihat dan mengamati secara langsung pada keadaan yang sebenarnya. Dan peneliti dapat mengetahui secara langsung situasi dan kondisi dari objek yang diteliti.

Observasi dilakukan agar peneliti mendapatkan sendiri informasi yang dibutuhkan dalam penelitian dengan melakukan pengamatan. Iskandar menyatakan alasan peneliti melakukan observasi adalah untuk menyajikan gambaran realistik perilaku atau kejadian, untuk menjawab pertanyaan, untuk membantu mengerti perilaku manusia, dan untuk evaluasi yaitu melakukan pengukuran terhadap aspek tertentu melakukan umpan balik terhadap pengukurantersebut.

b. Wawancara

Wawancara adalah percakapan dengan maksud tertentu, yang dilakukan oeh dua pihak pewawancara dan terwawancara dengan 
312 AT-TAWASSUTH: Jurnal Ekonomi Islam, Volume IV No. 2 Juli Desember 2019: 301 - 322

menggunakan pertanyaan-pertanyaan untuk mengkonstruksi mengenai orang, kejadian, aktifitas organisasi, motivasi, tuntutan dan kepedulian. Wawamcara dala, penelitian kualitaitf sifatnya mendalam karena ingin mengeksplorasi imformasi secara holistic dan jelas dari informan. ${ }^{21}$

Dalam penelitian kualitatif, metode wawancara menjadi pilihan favorit karena diharapkan bisa mendapatkan data yang diinginkan dengan lebih mendalam sehingga akan dapat lebih mudah diambil kesimpulan dari data yang diperoleh. Lancarnya kegiatan wawancara tergantung pada kedua belah pihak sebagai pelaku wawancara dimana pewawancara yang memberikan sejumlah pertanyaan kepada terwawancara dan kemudian menjawab beberapa pertanyaan yang diajukan. Selain itu juga tergantung pada situasi dan kondisi saat wawancara dilakukan, baik tempat, kondisi pewawancara dan terwawancara, waktu pelaksanaan wawancara, dan juga hubungan antara kedua belah pihak.

Dalam wawancara dipilih informasi yang mempunyai criteria sebagai berikut: 1. Subjek cukup lama dan intensif menyatu dengan medan aktifitas yang menjadi sasaran peneliti, 2. Subjek masih aktif terlibat dilingkungan aktifitas yang menjadi sasaran penelitian. 3. Subjek yang masih mempunyai waktu untuk dimintai informasi dan mau memberikan informasi yang sebenarnya. ${ }^{22}$

c. Dokumentasi

Dokumentasi menjadi metode pengumpulan data yang dapat digunakan untuk mendorong data yang sudah di peroleh dan mendukung teknik observasi dan wawancara yang sudah dilakukan. Sugiyono menyatakan studi dokumen merupakan pelengkap dari penggunaan metode observasi dan wawancara dalam penelitian kualitatif. Teknik ini mengumpulkan dokumen-dokumen yang dibutuhkan berhubungan dengan masalah yang diteliti sehingga dapat mendukung dan membuktikan terhadap suatu masalah. Dokumen ini juga dapat menambah informasi untuk peneliti terutama data-data yang tidak bisa di deskripsikan melalui kata-kata. 


\section{Hasil Penelitian}

Strategi fundraising wakaf di pondok pesantren mawaridussalam dalam menghasilkan jumlah wakif dan nominal yang diwakafkan. Berbagai upaya fundraising dilakukan dalam mencapainnya. Strategi-strategi yang dilakukan melalui beberapa cara atau metode yang sudah disusun secara rinci, perumusan yang spesifik, dan penetapan targetnya sebagai program fundraising wakaf. Langkah strategis yang dilakukan sebagai persiapan untuk merencanakan fundraising, yaitu: rencana program strategis jangka panjang, merancang budget jangka panjang, menetapkan skala prioritas program, membangun sknario fundraising, menetapkan tujuan fundraising, menyusun strategi fundraising, melakukan identifikasi dana. ${ }^{23}$ Namun proses dari implementasi dari setiap langkah strategis ini terdapat kelemahan-kelemahan yang membuat setiap rumusan terkendala.

Secara teori konseptual badan nadzir wakaf pondok pesantren mawaridussalam memiliki peluang yang unik untuk menciptakan peluang dan mendapatkan hasil dari setiap fundraising wakafnya. Adapaun konsep dan strategi sasaran yang dilakukan badan wakaf pondok pesantren mawaridussalam yakni: melakukan rapat koordinasi untuk perencanaan yang dilakukan oleh tim fundraising, membagi tugas wilayah atau lokasi target wakif baru, melakukan skala prioritas, mempersiapkan bahan untuk menghadapi calon wakif yang akan di follow up menjadi wakif, memperhatikan dari data diri individu yang didapatkan dari imforman baik teman, relasi maupun tetangga dan lain sebagainya.

Prospek dari tindak lanjut dari sebuah program fundraising yang di lakukan oleh badan wakaf pondok pesantren mawaridussalam juga memiliki metode sebagai berikut diantaranya: dalam penghimpunan dana dengan silaturahim kepada calon donator yang telah di prospek, baik itu lembaga pemerintah, keuangan seperti perbankan syariah, dan masyarakat. Melalui nomor rekening dan pejemputan wakaf, donator tetap maupun tidak tetap dilakukan dengan permohonan proposal wakaf, membuat event sosial dengan menampilkan produk wakaf sekaligus ditawarkan kepada masyarakat, kerjasama dengan bank syariah, seperti bank muamalat. Sebab memiliki keunggulan teknis dalam mengelola 
314 AT-TAWASSUTH: Jurnal Ekonomi Islam, Volume IV No. 2 Juli Desember 2019: 301 - 322

keuangan sehingga memungkinkan optimalisasi fundraising wakaf dan di harapkan akan lebih mengefektifkan sosialisasi keberadaan wakaf seiring tingginya akses masyarakat terhadap jasa keuangan. Selanjutnya mensosialisasikan kepada masyarakat didukung tokoh setempat dengna mengadakan pengajian maupun kegiatan yang terkait bermasyarakat. Sedangakan beberapa cara atau metode yang dilakukan dalam fundraising wakaf dari masyarakat yang diungkapkan oleh divisi pendanaan wakaf pondok pesantren mawaridussalam antara lain : Acara tahunan (buka puasa bersama 6000 jama'ah), sosialisasi santri kepada keluarganya, sosialisasi ke tamu - tamu, stoke holder dan program jemput waka dan pembinaan wakif. ${ }^{24}$

\section{Acara Tahunan}

Badan wakaf pondok pesantren mawaridussalam merencanakan sebuah program tahunan sebagai strategi fundraising wakafnya. yaitu buka puasa bersama di bulan Ramadhan. Acara ini dilaksanakan dengan tujuan menjalin tali silaturahim dengan masyarakat dan para wali santri. Kegiatan ini dihadiri oleh para tokoh - tokoh masyarakat, para wali santri, anak yatim dan para tamu - tamu undangan yagn turut berpartisipasi dan hadir dalam kegiatan ini. Dengan adanya kegiatan ini, akan semakin memperkuat citra baik dan jaringan dalam mengembangkan pondok pesantren Mawaridussalam. Maka kegiatan ini menjadi program rutinitas yang dilaksanakan pada setiap tahunnya.

"Sudah menjadi sunnah tahunan, sejak berdiri tahun 2010 Ponpes Mawaridussalam selalu mengadakan buka puasa bersama wali santri, anak yatim, masyarakat sekitar dan tokoh - tokoh masyarakat di Sumatera Utara. Jumlah jama'ah yang hadir pada setiap buka puasa bersama pun terus meningkat. Pada tahun pertama dan kedua, jamaah yang hadir hanya ratusan dan terus meningkat setiap tahun pertahun, kemudian pada tahun 2019, hari jum'at pukul 14.00 sampai dengan selesai (Tanggal 24 Mei 2019) buka puasa bersama di Ponpes Mawaridussalam yang dihadiri KH. Tengku Zulkarnain dan Buya KH. Syahid Marqum beserta 6.000 jama'ah. Acara ini pada tahun tahun yang lalu dihadiri Tuan Guru Besilam Syeikh Hasyim al-Syarwani, Ketua PP Sumatera Utara H. Kodrat Shah, Guru Besar IAIN Lampung Prof. Dr. 
Syarifuddin Basyar, Kakan Kemenag Del Serdang, Pimpinan PT Indofood CBP Sukses Makmur Tbk Elvin Santoso dan tamu undangan lainnya. ${ }^{25}$

Pada kegiatan ini jugalah pihak pesantren melakukan fundraising dana, baik wakaf, infak ataupun sedekah dengan memberikan penjelasan tentang program - program pembangunan ataupun lainnya dalam kepentingan pendidikan. namun perlu ditegaskan bahwa acara ini tidak semata - mata hanya untuk fundraising dana wakaf, meskipun itu menjadi salah satu tujuannya. Dalam acara ini juga memberikan perkembangan pondok pesantren mawaridussalam yang perlu diketahi oleh masyarakat. Seperti yang pernah disampaikan oleh Drs. K.H. Syahid Marqum dalam sambutan acara buka puasa bersama:

"Acara buka puasa bersama ini bukan untuk nodong bapak ibu agar berinfaq dan berwakaf, tetapi sebagai bukti bahwa pondok ini adalah wakaf orang banyak, pimpinan dan dewan nazhir wakaf di sini harus dikontrol masyarakat. Melalui penggalangan wakaf seperti ini akhirnya masyarakat punya hak kontrol"

Dengan menghadirkan para tokoh - tokoh dan di isi tausiah oleh para Alim Ulama, memotivasi dan mengajak semua jamaah yang hadir untuk menyalurkan bantuannya kepada ponpes Mawaridussalam. Pemberian Penguatan dan motivasi kepada seluruh jamaah untuk berderma menjadi sebuah cara penyampai pesan yang lebih efektif. Pada saat ini jugalah pengumpulan dana dibuka oleh panitia yang bertugas. Seperti yang tergambar dalam tulisan kalam Mawaridussalam dan juga diliput dalam harian analisa yang meliput kegiatan tahunan ini.

Prof. Syarifuddin Basyar dari IAIN Lampung turut memberikan tausiah sekaligus memompa semangat hadirin berlomba - lomba dalam berwakaf sebagai bekal akhirat. "Tidak ada ruginya bapak ibu menyantrikan anak-anaknya ke pondok pesantren. Dan tidak akan mengurangi harta bapak ibu sekalian harta yang bapak sedekahkan atau wakafkan. Bahkan harta sedekah dan wakaf itu menjadi bekal akhirat yang memberatkan timbangan kita kelak, apalagi wakaf ke pondok pesantren mawaridussalam, selama pondok ini berkembang, amal jariyah wakaf kita pun terus mengalir, bahkan semakin besar. Di tengah-tengah orasi Prof. Syarifuddin, para santri petugas penggalang dana wakaf berkeliling ke tengah - tengah jamaah untuk mengambil wakaf mereka. Setelah acara terkumpul 
316 AT-TAWASSUTH: Jurnal Ekonomi Islam, Volume IV No. 2 Juli Desember 2019: 301 - 322

dana Rp. 35.000.000,00 (tiga puluh lima juta rupiah) untuk pembangunan Ponpes Mawaridussalam. Acara ditutup dengan doa yang dipimpin Tuan Guru Besilam Syeikh Hasyim al-Syarwani. ${ }^{26}$

Begitu juga yang pernah dilakukan pada tahun 2015 pada bulan Ramadhan 1436 H. Pondok Pesantren Mawaridussalam melaksanakan acara dihadiri lebih kurang 5000 jamaah, terdiri dari santri, wali santri, anak yatim piatu, masyarakat sekitar dan tokoh masyarakat Sumatera Utara. Lebih dari $90 \%$ wali santri hadir karena sekaligus untuk menjemput anaknya liburan puasa dan hari raya. fundraising dana yang dilakukan dalam buka puasa bersama tersebut terkumpul dana lebih kurang Rp. 70.000.000,00 (Tujuh puluh juta rupiah). ${ }^{27}$

\section{Sosialisasi Santri Kepada Keluarganya}

Teknik sosialisasi wakaf sebenarnya banyak cara yang bisa dilakukan. Namun dalam bahasan ini adalah adanya ikut andil para santri dalam mensosialisasikan wakaf kepada orang tua ataupun keluarganya. Sehingga pesan yang disampaikan secara langsung oleh santri yang belajar di pondok pesantren Mawaridussalam. Strategi sosialisasi seperti ini punya kelebihan tersendiri karna yang menyampaikan adalah anaknya sendiri dan status sebagai santri yang dibina di pondok pesantren Mawaridussalam.

Selain strategi sosialisasi seperti ini, pondok pesantren Mawaridussalam juga telah banyak melalui medai massa, seperti surat kabar, majalah, brosur, webswite, spanduk dan sebagainya. Seperti yang telah dijelaskan di atas bahwa acara - acara kegiatan besar ponpes Mawaridusslam juga diliput oleh media massa surat kabar. Sehingga media massa cetak ini tentunya akan banyak beredar luas di tengah masyarakat. Memanfaatkan kecanggihan teknologi media sosial menjadi sebuah keharusan untuk dilakukan dalam sosialisasi wakaf. Dengan media inilah masyarakat mudah mendapatkan informasi - informasi seputar perkembangan ponpes Mawaridussalam.

\section{Sosialisasi Ke Tamu-Tamu Dan Stake Horlder}

Salah satu ajaran di Pesantren Mawaridussalam adalah memuliakan tamu tamu yang datang dan berkunjung. Tentunya sangat kental diajarkan oleh para Kiyai kepada santri - santrinya. Dan ini juga adalah anjuran dalam ajaran Islam 
itu sendiri. Nilai - nilai seperti ini masih sangat terjaga dalam kehidupan ponpes Mawaridussalam. Sehingga menjadi sautu kelebihan yang baik dipandang oleh masyarakat luas.

K.H. Syahid Marqum sebagai pimpinan pondok pesantren mawaridussalam sering mengungkapkan "tamu pasti membawa berkah" bahkan Rasulullah saw dengan tegas menyatakan bahwa salah satu ukuran dan tanda bagi kesempurnaan iman seseorang adalah seberapa dia mampu menghormati tamu. Untuk itu kita harus memuliakan tamu sebaik mungkin, karena tamu ibarat mata ketika datang mulut ketika pergi, sehingga bisa menjadi duta yang dsignifikan bagi ponpes Mawariudussalam.

Pondok pesantren Mawaridussalam dengan segala kesederhanaannya ternyata memiliki daya pikat sendiri bagi setiap orang yang mengenalnya. Setiap yng mendengar tentang perkembangannya, banyak yang penasaran dan ingin mengunjunginya, ingin melihat langsung seperti apa ponpes yang mereka sebut dengan fenomenal itu. Dari tahun ke tahun sejak berdiri tahun 2010, frekuensi kedatangan tamu terus meningkat, baik pribadi maupun rombongan, dari dalam negeri sampai tamu luar negeri.

Semakin banyak tamu yang datang menandakan semakin luasnya network yang terjalin antara Ponpes Mawaridussalam dengan berbagai lembaga. Semoga hal ini terus berlanjut, yang dapat dijadikan tolok ukur eksistensi Ponpes Mawaridussalam bagi masyarakat. Sejak awal berdiri, banyak bantuan yang diberikan oleh Dinas Tata Ruang dan Permukiman (Tarukim) kepada Ponpes Mawaridussalam, antara lain rumah kompos, sanitasi dan kamar mandi, jalan pavling block dan lain - lain. Pada tanggal 8 Agustus 2015, peserta latihan Dinas tarukim Angkatan I berkunjung ke Mawaridussalam untuk melihat pemanfaatan dan perwatan bantuan - bantuan yang pernah diberikan. Demikian juga dengan peserta pelatihan Dinas tarukim angkatan II yang mengadakan kegiatan yang sama.

Berbagai kalangan tamu yang dating berkunjung ke Pondok Pesantren Mawaridussalam. Diantaranya seperti Dosen Universitas Islam Madinah. Mereka adalah Syeikh Abdul Aziz, Syeikh Mubarak dan Syeikh Tariq. Direktur Baitul Maal Muamalat Pusat, Sekjen MIUMI Pusat, Surveyor BRI dan Wakil Direktur 
318 AT-TAWASSUTH: Jurnal Ekonomi Islam, Volume IV No. 2 Juli Desember 2019: 301 - 322

BRI Pusat, Donatur AMCF Jakarta, Menristek Dikti, Dosen - dosen berbagai perguruan tinggi Amerika Serikat, Dibirnas POLDASU, Dubes Arab Saudi, Anggota DPR RI, dan masih banyak lainnya yang datang sebagai tamu ponpes Mawaridussalam.

\section{Strategi Jemput Wakaf}

Badan wakaf mawaridussalam juga menyediakan layanan program jemput wakaf. layanan ini disediakan untuk memudahkan bagi masyarakat yang ingin berwakaf ke Ponpes Mawaridussalam. Masyarakat hanya perlu menghubungi pengurus untuk menyampaikan niat baiknya, dan para pengurus akan turun langsung menjemput wakaf tersebut. Cara ini merupakan salah satu bentuk startegi fundraising wakaf pondok pesantren mawaridussalam untuk menghimpun dana wakaf dari masyarakat. Dengan strategi ini diharapakan semakin banyak yang ingin berderma mewakafkan sebagian hartanya ke Ponpes Mawaridussalam. Karena sudah ada kemudahan yang disediakan dalam bentuk merespon dengan sebaik mungkin keinginanan masyarakat untuk berwakaf.

Program lain yang dikonsep oleh lembaga zakat imfak sedekah dan wakaf Mawaridussalam adalah strategi tabungan wakaf. program ini ditujukan untuk masyarakat yang menyisihkan sebagian uangnya sebagai tabungan wakaf. Tabung wakaf ini tetap berada di rumah si wakif dengan menabung berapapun nominal yang diinginkannya. Pada saatnya nanti ketika sudah terkumpul banyak, akan dijemput oleh petugas kerumah si wakif masing - masing.

Program ini merupakan solusi bagi yang ingin berwakaf, tetapi tidak memiliki harta yang banyak. Sebuah terobosan yang dibuat oleh Tim lembaga zakat imfak sedah wakaf mawaridussalam. Selama ini pemahaman masyarakat untuk berwakaf, kesannya harus kaya lebih dahulu. Hal ini merupakan pemahaman yang keliru, maka melalui tabung wakaf ini, siapapun bisa berwakaf. Apapun profesinya baik pedagang asongan, penjual gorengan, tukang becak, apalagi yang lebih mampu dari itu.

Sistem kerjanya adalah dengan memasukkan recehan - recehan yang sering diremehkan. Saat sudah banyak, hasil tabung bisa diserahkan ke lembaga zakat imfak sedekah dan wakaf, tabungnya tetap di rumah untuk diisi kembali. Jika 
sering - sering menyetor, akan nampak sudah berapa harta yang kita wakafkan kepada Pondok pesantren Mawaridussalam. ${ }^{28}$

Banyak cara yang bisa dilakukan dalam menghimpun wakaf dari masyarakat seperti yang sudah dijelaskan pada bahasan sebelumnya di atas. Salah satunya adalah menghimpun wakaf masyarakat melalui dunia usaha atau bisnis. Menghimpun wakaf melalui dunia usaha masyarakat merupakan salah satu potensi dan peluang yang baik. Menurut penjelasan Direktur lembaga zakat imfak sedekah wakaf pondok pesantren Mawaridussalam, upaya ini sudah dilakukan, dengan melakukan sosialisasi dan pengajuan proposal ke beberapa usaha masyarakat, namun belum memperoleh hasil sesuai dengan yang diinginkan. Nampaknya perlu ada contoh dari dalam ataupun harus dimulai dari dalam terlebih dahulu. Agar bisa dilihat masyarakat sebagai bandingan ataupun referensi. Sampai saat ini lembaga zakat imfak sedekah wakaf masih tetap melakukan upaya tersebut agar terealisasi sesuai dengan apa yang sudah dikonsepkan bersama.

\section{Broadcast Ta'lim Dan Pembinaan Wakif}

Broadcast Ta'lim dan Pembinaan Wakif di sini maksudnya adalah mengedarkan tulisan singkat melalui sosial media tentang ilmu-ilmu agama. Selain tentang kajian keIslaman di akhir tulisanpun disertakan ajakan untuk berwakaf dan menyebutkan bentuk wakaf yang sedang berjalan. Kemudian disertakan pula nomor rekening untuk pengumpulan dana wakafnya. Strategi ini di lakukan oleh badan wakaf mawaridussalam untuk menjaga kesinambungan dan komitmen wakif terhadap keislaman dan perjuangan mereka terhadap ummat. Selain itu untuk menjaga loyalitas terpeliharan dan semakin meningkat. Pembinaan wakif ini juga di lakukan melalui forum-forum pengajian maupun pertemuan-pertemuan informal. Meskipun materi pengajiannya bersifat umum, namun pada sesi Tanya jawab setelah pengajian disediakan ruang untuk wakif berkonsultasi dan diskusi berbagai hal mengenai wakaf dan pengembangannya.

\section{Kesimpulan}

Konsep strategi fundraising wakaf di badan wakaf pondok pesantren mawaridussalam yang dilakukan yaitu melalui agenda tahunan yaitu dengan mengadakan kegiatan buka bersama dengan jama'ah, sosiali santri kepada 
320 AT-TAWASSUTH: Jurnal Ekonomi Islam, Volume IV No. 2 Juli Desember 2019: 301 - 322

keluarganya, sosialisasi pihak badan wakaf terhadap tamu-tamu dan stackholder, program-program jemput wakaf.

Dampak dari strategi fundraising yang digunakan lembaga badan wakaf mawaridussalam yakni terjadinya peningkatan pengetahuan, kepercayaan, motivasi, serta terdorongnya para wakif untuk berwakaf di kesempatan berikutnya dan peningkatan pengalaman berwakaf. Terciptanya kedekatan personal, tersampaikannya kendala dan terciptanya komunikasi dua arah. Selain itu strategi fundraising juga memberikan dampak peningkatan edukasi, penguatan jumlah data prospek dan tersampaikannya program program badan wakaf mawaridussalam kepada masyarakat, stackholder.

\section{Catatan}

${ }^{1}$ Juhaya S. Praja, Perwakafan Indonesia, Sejarah Pemikiran, Hukum, dan Perkembanganya, (Bandung; Yayasan Plara, 1995) Hal. 1.

${ }^{2}$ Hendri suheri, Fiqh Muamalah (Jakarta: Raja Grafindo Persada), Hal. 13.

${ }^{3}$ Adijani Al-Alabij, PerwakafanTanah di Indonesia dalam Teori dan Praktek (Jakarta: Raja Grafindo Persada, 1997), Hal. 23.

${ }^{4}$ Direktorat Pemberdayaan Wakaf dan Direktorat Jenderal Bimbingan Masyarakat Islam, Paradigma Baru Wakaf di Indonesia, (Jakarta: Departemen Agama RI, 2007), Hal. 2.

${ }^{5}$ Azhari Akmal Tarigan dan Agustianto, Wakaf Produktif Pemberdayaan Ekonomi Ummat, (Medan: IAIN Pres, 2004) Hal. 35

${ }^{6}$ Peraturan Pemerintah No. 42 Tahun 2006 Tentang Pelaksanaan Undang-Undang No. 41 Tahun 2004 Tentang Wakaf.

${ }^{7}$ Hendrawan Supratikno, Advanced Strategic Manajement: Back To Basic Approach (Jakarta: Grafindo Persada, 2003), Hal.19.

${ }^{8}$ Hasan Alwi, dkk., Pusat Bahasa Departemen Pendidikan Nasional RI, Kamus Besar Bahasa Indonesia, Edisi Ketiga, (Jakarta: Balai Pustaka, 2005) Hal. 1092

${ }^{9}$ Hadari Nawawi, Manajemen Strategi, (Yogyakarta: Gajah Mada University Press, Cet 2, 1996) Hal. 33

${ }^{10}$ Stainer, George \& John Miller, Manajemen Strategi, (Jakarta :Erlangga, 2008). Hal. 65

${ }^{11}$ Fred R. David, Manajemen Strategi Konsep, Ter. Dari Strategic Manajement (Jakarta: Prenhalindo, 2002), Hal.30

${ }^{12}$ Manajemen Pengelolaan Zakat (Jakarta: Direktorat Pemberdayaan Zakat, Dierektorat Jendral Bimbingan Masyarakat Islam Departemen Agama RI, 2009), Hal. 65.

${ }^{13}$ April Purwanto, Manajemen Fundraising bagi Organisasi Pengelola Zakat, (Yogyakarta: Sukses, 2009), Hal. 12. 
${ }^{14}$ Ahmad Juwaini, Panduan Direct Mail Untuk Fundraising, (Depok, Piramedia, 2005) Hal. 8

${ }^{15}$ Didin Hafhiduddin dan Ahmad Juwaini, Membangun Peradaban Zakat, (Ciputat: IMZ, 2006) Hal.56

${ }^{16}$ Suharsimi Arikunto, Prosedur Penelitian: Suatu Pendekatan Praktek (Jakarta: Bina Aksara, 2012) Hal. 27

${ }^{17}$ Nurul Zuriah, Metodologi Penelitian Sosial dan Pendidikan, (Bandung: Bumi Aksara, 2006) Hal. 92

${ }^{18}$ Sugiyono, Metode Penelitian Bisnis,(Bandung : Alfabeta, 2012) Hal.14

${ }^{19}$ Nana Syaodi Sukmmadinata, Metode Penelitian Pendidikan, (Bandung: Remaja Rosdakarya, 2007). Hal.60

${ }^{20}$ S. Margono, Metodologi Penelitian Pendidikan (Jakarta, Rineka Cipta, 1997) Hal. 158

21 Djam'an Satori dan Aan Komariah, Metodologi Penelitian Kualitatif ( Bandung: Alfabeta, 2009) Hal.130

${ }^{22}$ Burhan Bungin, Penlitian Kualitatif, Ekonomi, kebijakan Public dan Ilmu Sosial lanya, (Jakarta: Kencana, 2012) Hal. 119

${ }^{23}$ Wawancara dengan direktur wakaf pondok pesantren mawaridussalam, 25-26 Mei 2019

${ }^{24}$ Wawancara dengan divisi pendanan wakaf pondok pesantren mawaridussalam, 22-23 Juni 2019

${ }^{25}$ Wawancara bersama seketaris wakaf pondok pesantren mawaridussalam, 25-26 Mei 2019

${ }^{26}$ Wawancara bersama divisi pendanaan wakaf pondok pesantren mawaridussalam, 22-23 juni 2019

${ }^{27}$ Wawancara dengan bendahara lembaga zakat imfak sedekah wakaf pondok pesantren mawaridussalam, 22-23 juni 2019

${ }^{28}$ Wawancara dengan divisi pendanaan lembaga zakat imfak sedekah wakaf pondok pesantren mawaridussalam, 22 -23 juni 2019

\section{Daftar Pustaka}

Juhaya S. Praja. 1995, Perwakafan Indonesia, Sejarah Pemikiran, Hukum, dan Perkembanganya, Bandung; Yayasan Plara

Suheri, Hendri Fiqh Muamalah,Jakarta: Raja Grafindo Persada

Al-Alabij, Adijani, 1997, PerwakafanTanah di Indonesia dalam Teori dan Praktek, Jakarta: Raja Grafindo Persada

Akmal Tarigan, Azhari dan Agustianto, 2004, Wakaf Produktif Pemberdayaan Ekonomi Ummat, Medan: IAIN Pres

Supratikno, Hendrawan, 2003, Advanced Strategic Manajement: Back To Basic Approach Jakarta: Grafindo Persada 
322 AT-TAWASSUTH: Jurnal Ekonomi Islam, Volume IV No. 2 Juli Desember 2019: 301 - 322

Hasan Alwi, dkk. 2005, Pusat Bahasa Departemen Pendidikan Nasional RI, Kamus Besar Bahasa Indonesia, Edisi Ketiga, (Jakarta: Balai Pustaka

Nawawi, Hadari,1996 Manajemen Strategi, Yogyakarta: Gajah Mada University Press, Cet 2

Stainer, George \& John Miller, 2008, Manajemen Strategi, Jakarta: Erlangga

Fred R. David, 2002 Manajemen Strategi Konsep, Ter.Dari Strategic Manajement Jakarta: Prenhalindo

Purwanto, April, 2009, Manajemen Fundraising bagi Organisasi Pengelola Zakat, Yogyakarta: Sukses

Juwaini,Ahmad, 2005,Panduan Direct Mail Untuk Fundraising,Depok, Piramedia

Hafhiduddin, Didin, Dkk, 2006, Membangun Peradaban Zakat, Ciputat: IMZ

Arikunto, Suharsimi, 2012, Prosedur Penelitian: Suatu Pendekatan Praktek Jakarta: Bina Aksara

Zuriah, Nurul, 2006 Metodologi Penelitian Sosial dan Pendidikan, Bandung: Bumi Aksara

Sugiyono, 2012, Metode Penelitian Bisnis, Bandung : Alfabeta

Sukmmadinata, Nana Syaodi, 2007, Metode Penelitian Pendidikan, Bandung: Remaja Rosdakarya

S. Margono, 1997,Metodologi Penelitian Pendidikan Jakarta: Rineka Cipta

Satori, Djam'an, Dkk,2009, Metodologi Penelitian Kualitatif, Bandung: Alfabeta

Burhan Bungin, 2012, Penlitian Kualitatif, Ekonomi, kebijakan Public dan Ilmu Sosial lanya, Jakarta: Kencana

David, Fred R. 2006. Manajemen Strategi, Ed ke-10. Jakarta: Salemba Empat.

Moleong, Lexy J, Metode Penelitian, dikutip dari http;//Google Cendekia.ac.id/ artikel.

Muhadjir, Noeng. 2000. Metodologi Penelitian Kualitatif, edisi IV. Yogyakarta:

Rake Sarasin. 